\title{
IMPROVEMENT OF VIBRATORY CONVEYING AND MANIPULATING MACHINES
}

\section{Vitaliy Korendiy; Vladyslav Shenbor; Oleksandr Havrylchenko; Volodymyr Brusentsov}

\author{
Lviv Polytechnic National University, Lviv, Ukraine
}

\begin{abstract}
Summary. In the paper, the technical and operational peculiarities of vibratory conveying and manipulating machines, as well as their implementation fields, are considered. The improved design diagram of the conveying and manipulating device is proposed and its advantages are substantiated. The principal schemes of piece products conveying process are presented. The methodology of determining the parameters of the spring system of the improved conveyer is developed taking into account the necessity to ensure safety operation of springs being under the influence of longitudinal, lateral, and angular vibrations. The electric circuit diagrams of feeding the coils of electromagnets are designed and various processes of the products conveying are considered. The principal schemes of implementing the proposed vibratory conveying and manipulating machines in the field of industrial automation are presented.

Key words: vibratory conveyer, transporting and manipulating device, spring system, design diagram, vibration, electrical circuit diagram, industrial automation.
\end{abstract}

Introduction and statement of the problem. The processes of conveying, manipulating, stacking, packing, separating, sorting the piece products are of the most important parts of industrial mechanization and automation. The automation of various industrial processes allows more efficient using of technological equipment and even helps to solve some social problems due to dispensing the human beings from the non-creative monotonous manual labour [1 - 8].

Vibratory conveying and manipulating machines with electromagnetic drive can be effectively used in various automated and mechanized industries, robotic systems, flexible manufacturing systems etc. Such devices provide conveying the products in any direction of the conveying plane and rotating them round their axes in any zone of the plane. These peculiarities of vibratory conveyers allow arranging and sorting the products, moving them to any zone of the conveying plane with further feeding of different technological equipment. Due to the mentioned advantages, these devices are characterized by high operational flexibility and efficiency. Despite such peculiarities, their small power consumption, absence of friction pairs, relative simplicity of structures, they have not yet been widely used in industrial processes. This can be explained by the lack of information representation of vibratory equipment and the low interest of enterprises in implementing new technologies.

While developing new vibratory machines, an important task is to maximize their efficiency, in particular, the efficiency of their mechanical oscillatory systems, electromagnetic vibration exciters, multicomponent spring systems etc. Therefore, the designers face quite complicated problems of improving the known or developing new structural and design diagrams of vibratory devices in order to expand their technological capabilities, and to substantiate the methods of parameters determination.

Analysis of the available investigations. A major contribution to the development of industrial automation was made by numerous famous scientists and researchers, in particular by N. Kamyshnyi, I. Klusov, A. Malov, A. Rabinovich and others. However, the problems 
related with manipulating and transporting the products in any direction of the conveying plane are not paid enough attention. Herewith, the problems of arranging the products in sets, manipulating and transporting easy-to-damage (damageable) products along a plane, group orientation of outsized and off-gauge products are of the most complicated ones. The research on products manipulation without their gripping was carried out by A. Ivanov, V. Povidailo, Z. Stotsko, V. Shchigel [1, 2, 5, 9-11]. These researchers solved the problems of arrangement in sets of the simple-shape piece products with a rather strong surface layer and with sufficient rigidity. The most well-known foreign enterprises working on the similar problems are: Vimarc, FMC corp., Hoesler Machine Tools, Tissen Industry, Sanko-Koto, Okura, Farchild, Delta Design, Daymarc etc.

The first vibratory conveying devices with electromagnetic drive and elliptical oscillations of the working body were designed and implemented in practice by the team of researchers under the direction of Professor Povidailo V.O. in the early 80s of the 20th century. The developed equipment was mainly designed on the basis of two copyright certificates $[1,2]$ and launched an active investigations on implementation of an entire range of vibratory reversible and shuttle conveyers, as well as numerous conveying and manipulating machines. The implemented equipment was effectively used in the processes of automation and mechanization of products manufacturing and in robotic technological complexes. Most equipment was experimentally tested in order to provide the optimal operation modes while conveying piece products in different directions along a plane using elliptical oscillations of the working bodies $[5,10,11]$.

This paper presents recent achievements of the Department of Mechanics and Automation Engineering of Lviv Polytechnic National University in the field of industrial automation by means of vibratory technologies. A significant part of this research have already been published in [6-8], and this paper considers the peculiarities of developing the improved designs of vibratory conveying and manipulating equipment.

The objective of the present work consists in improvement of the known designs of vibratory conveying and manipulating devices in order to extend their operational capabilities, to develop the methodology of determination of their parameters, and to simplify the possibilities of their implementation while performing automation of various manufacturing and technological processes.

Analysing the improved design of vibratory conveying and manipulating machine. The known designs of vibratory conveying and manipulating devices allow transporting of the piece products (parts) in any direction of a square (rectangular, circular) conveying plane (Fig. 1, a), and rotating the parts in any zone of the plane ( Fig. 1, b) [5].

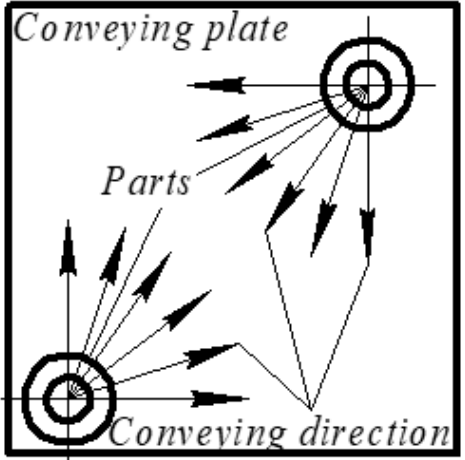

a)

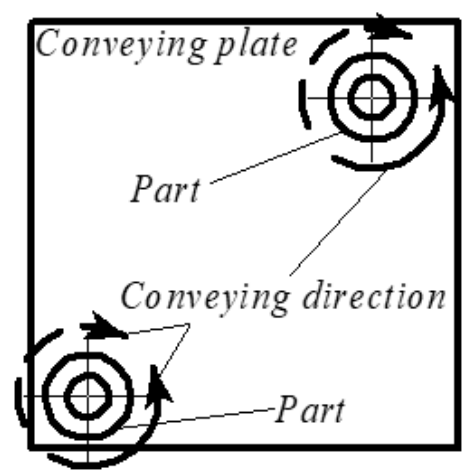

b)

Figure 1. Schemes of conveying piece products on a plane: a - translational conveying in any direction of a plane; $b$ - parts rotating in any zone of a plane 
The improvement of vibratory conveying devices consists in extending their functionality and operational capabilities. The improved device (Fig. 2) is designed on the basis of three-mass mechanical oscillatory system and consists of three oscillating masses $m_{1}, m_{2}$ and $m_{3}$ connected by combined spring systems.

The working body (mass $m_{1}$ ) consists of conveying and manipulating plate 1 , rigid square drum 2, electromagnet 12 of vertical vibrations, two pairs of electromagnets' armatures of longitudinal vibrations and two pairs of electromagnets' armatures 11 of lateral vibrations. Herewith, the pairs of electromagnets are placed at the angle of $90^{\circ}$. All the parts of the working body form a rigid structure.

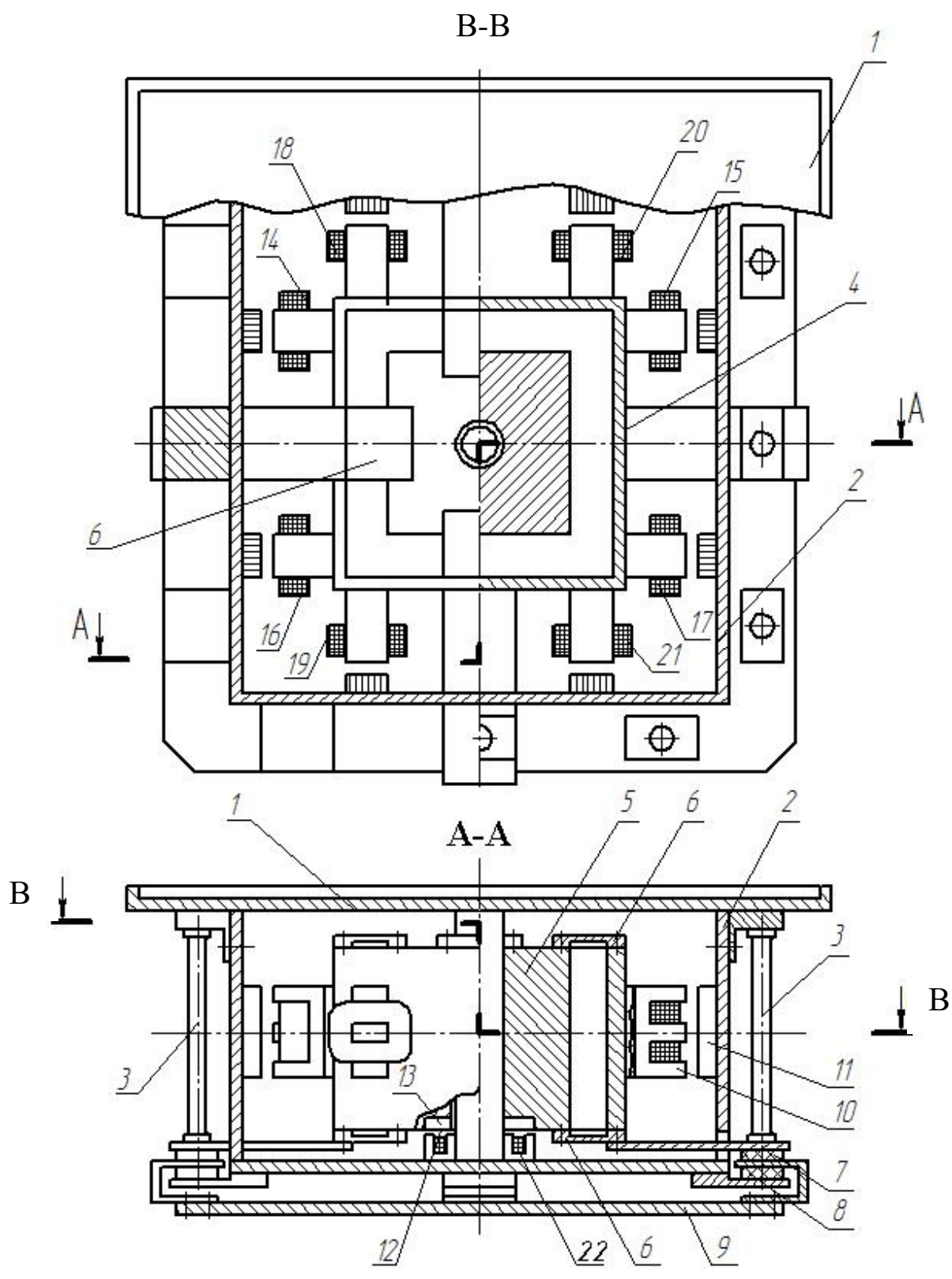

Figure 2. Design diagram of the improved conveying and manipulating machine: 1 - comnveying and manipulating plate; 2 - rigid drum of the working body; 3 - rod-type cylindrical spring elements; 4 - rigid square box of the intermediate mass; 5 - thick-wall square bar; 6 - flat springs; 7, 8 - vibration isolators;

9 - unmovable base; 10, 11 - ores and armatures of the electromagnets of horizontal vibrations;

12 - electromagnet of vertical vibrations; 13 - armature of the electromagnet of vertical vibrations;

14, 15, 16, 17 - electromagnets of longitudinal vibrations; 18, 19, 20, 21 - electromagnets of lateral vibrations; 22 - coil of the electromagnet of vertical vibrations 
The intermediate mass $m_{2}$ is designed as a rigid square box 4 , to the external surface of which two pairs of electromagnets 14, 16 and 15, 17 of longitudinal vibrations and two pairs of electromagnets 18, 20 and 19,21 of lateral vibrations are attached. The pairs of electromagnets are placed at the angle of $90^{\circ}$; their surfaces are parallel to the surfaces of corresponding armatures, and between the magnets and armatures there are set the same gaps. Each pair of electromagnets is located at the same distance from the coordinate axes (central axes of symmetry of the machine structure).

The reactive mass $m_{3}$ consists of the thick-wall square bar 5 , to which the armature 13 of the electromagnet of vertical vibrations is attached.

The masses $m_{1}$ and $m_{2}$ are connected by rod-type cylindrical elements 3 placed vertically. The intermediate mass $m_{2}$ and the reactive mass $m_{3}$ are connected by flat springs 6 placed horizontally along the coordinate axes. The vibration isolators 7,8 made of the elastic rubber are placed between the masses $m_{2}$ and $m_{3}$ in the zones of the weakest horizontal vibrations. Between the isolators, there are placed the brackets with a help of with the device is mounted on the base 9 .

The described design diagram of vibratory conveying and manipulating device has four degrees of freedom: longitudinal, lateral, vertical and angular vibrations of the masses $m_{1}, m_{2}$ and $m_{3}$ (herewith, the masses $m_{2}$ and $m_{3}$ move as one body in steady-state operation modes).

Developing the methodology of determining the parameters of the improved machine. The device should be designed and set up on the near-resonance operation mode. By determining the corresponding dimensions of the rod-type springs 3 and their placement, it is necessary to set the natural frequencies of longitudinal, lateral and angular vibrations equal to $1.04 \ldots 1.06$ of the forced frequency of the system (the frequency of the voltage applied to the electromagnets) [5]. The natural circular frequency of longitudinal and lateral oscillations can be determine by the following formula:

$$
\omega_{0_{n-n}}=\sqrt{\frac{c_{1} \cdot i}{m_{n-n}}}
$$

where $m_{n-n}=\frac{m_{1} \cdot\left(m_{2}+m_{3}\right)}{m_{1}+m_{2}+m_{3}}$ is the reduced mass of the vibratory system under the conditions of longitudinal or lateral vibrations; $c_{1}=\frac{12 \cdot E \cdot I}{l_{1}^{3}}$ is the longitudinal (lateral) stiffness of a single rod-type spring under the conditions of its bending and rigid fixation of its ends; $i$ is the number of rod-type springs; $I$ is the moment of inertia of the cross-section of the spring under the conditions of its bending. If a rod-type spring has circular cross-section, its stiffness in longitudinal and lateral directions is equal, and we can write $I=\frac{\pi \cdot d^{4}}{64}$, where $d$ is the diameter of the spring's cross-section; $l_{1}$ is the length of the non-fixed part of the spring; $E$ is the modulus of elasticity of the spring's material. Taking into account the fact that most such springs are made of spring steel, thus we have $E=2.1 \cdot 10^{11} \mathrm{~Pa}$.

The stiffness of the spring system under the conditions of longitudinal and lateral vibrations can be determined by the following system of equations: 


$$
\left\{\begin{array}{l}
c_{n-n}=\omega_{0_{n-n}^{2}}^{2} \cdot m_{n-n} \\
c_{n-n}=\frac{3 \cdot E \cdot \pi \cdot d^{4} \cdot i}{16 \cdot l_{1}^{3}}
\end{array}\right.
$$

In the second equation of the system (2), there was taken into account the rigid fixation of the springs' ends. This allows us to consider the fixation coefficient as $k_{3} \rightarrow 1$ [6]. The natural cyclic frequency is equal to $\omega_{0_{n-n}}=2 \cdot \pi \cdot v_{0_{n-n}}$, where $v_{0_{n-n}}$ is the natural frequency of the system's vibrations (i.e., the number of vibrations per second $\left[v_{0}\right]=\mathrm{Hz}$ ). Using the second equation of the system (2) and adopting the certain value $l_{1}$ of the working length of the rod-type spring and the number of springs $i$, we can derive the expression for determining the diameter of the spring's cross-section. If we need to provide the natural frequency of the system's vibrations equal to $v_{0_{n-n}}=52 \ldots .53 \mathrm{~Hz}$ (when the forced frequency is $v=50 \mathrm{~Hz}$ ), the following formula can be used for determining the diameter of the rod-type spring's crosssection:

$$
d=2,86 \cdot \sqrt[4]{\frac{v_{0 n-n}^{2} \cdot m_{n-n} \cdot l_{1}^{3}}{E \cdot i}}
$$

Considering the design diagram in Fig. 2, where $i=12$ and the springs are made of the spring steel, we obtain:

$$
d=2,27 \cdot 10^{-3} \cdot \sqrt[4]{v_{0 n-n}^{2} \cdot m_{n-n} \cdot l_{1}^{3}}
$$

The natural frequency of the angular vibrations (rotary vibrations about the vertical axis of symmetry of the structure) is equal to:

$$
\omega_{0 \varphi}=\sqrt{\frac{c_{\varphi}}{I_{36}}}
$$

where $I_{36}=\frac{I_{1} \cdot\left(I_{2} \cdot I_{3}\right)}{I_{1}+I_{2}+I_{3}}$ is the reduced central moment of inertia of the vibratory system under the condition of angular vibrations; $I_{1}, I_{2}, I_{3}$ are the central moments of inertia about the vertical axis if symmetry of the working, intermediate and reactive masses, respectively; $c_{\varphi}=i \cdot\left(c_{1} \cdot r^{2}+c_{\kappa p}\right)$ is the angular stiffness of the spring system; $r^{2}=\frac{1}{i} \cdot \sum_{k=1}^{i} r_{k}^{2}$ is the average radius of placement of the springs with respect to the vertical axis of symmetry; $c_{\kappa p}=\frac{G \cdot I_{\rho}}{l_{1}}$ is the torsional stiffness of the rod-type spring about its longitudinal axis; $I_{\rho}=\frac{\pi \cdot d^{4}}{32}$ is the polar moment of inertia of the spring's circular cross-section; $G$ is the shear (rigidity) modulus of the spring's material (for the spring steel $G=8,1 \cdot 10^{10} \mathrm{~Pa}$ ). 
The natural frequencies of longitudinal, lateral and angular vibrations should be equal: $\omega_{0_{n-n}}=\omega_{0 \varphi}$. In this case, let us substitute their values in (1) and (3) and determine the value of the radius $r$, which provides the equality of corresponding frequencies:

$$
r=\sqrt{\frac{I_{38}}{m_{n-n}}-\frac{c_{\kappa p}}{c_{1}}}
$$

Substituting the expressions for $c_{\kappa p}$ and $c_{1}$ into (6), we obtain:

$$
r=\sqrt{\frac{I_{36}}{m_{n-n}}-\frac{G}{6 \cdot E} \cdot l_{1}^{2}}
$$

The vibratory conveying and manipulating device designed with a help of the presented above formulas has the dimensions of the working plate of $500 \times 500 \mathrm{~mm}$ and the radius $r$ is in the range of $200 . . .240 \mathrm{~mm}$.

The natural frequency of vertical vibrations is to be $1.15 \ldots 1.3$ times larger than the forced frequency (the frequency of the voltage applied to the electromagnet 12 of vertical vibrations (see Fig. 2)). The larger deviation of the working (forced) frequency from the natural one is explained by the necessity to satisfy the conditions of self-stabilization of vibrations [5]. This allow conveying the piece products in wide range of their masses. The necessary value of the resonance correction coefficient is provided by choosing the appropriate dimensions of the flat springs 6 . The natural circular frequency of vertical vibrations can be determined by the formula:

$$
\omega_{06}=\sqrt{\frac{c_{2} \cdot i^{\prime}}{m_{b}}}
$$

where $m_{B}=\frac{\left(m_{1}+m_{2}\right) \cdot m_{3}}{m_{1}+m_{2}+m_{3}}$ is the reduced mass of the system under the conditions of vertical vibrations; $c_{2}=\frac{12 \cdot E \cdot I_{2}}{l_{2}^{3}}$ is the bending stiffness of the flat spring; $I_{2}=\frac{a^{3} \cdot b}{12}$ is the moment of inertial of the rectangular cross-section of the spring; $a, b$ are the thickness and the width of the spring's cross-section, respectively; $l_{2}$ is the working length of the flat spring (the length of the spring's unfixed part); $i^{\prime}$ is the number of flat springs.

Using the system of equation (5) and (8), let us determine the spring's thickness, which provides the necessary deviation of the natural frequency from the forced one:

$$
a=l_{2} \cdot \sqrt[3]{\frac{4 \cdot \pi^{2} \cdot v_{06}^{2} \cdot m_{6}}{E \cdot b \cdot i^{\prime} \cdot k_{3}}}
$$

where $v_{06}$ is the natural frequency of vertical vibrations; $k_{3}=0,8 \ldots 1,0$ is the fixation coefficient, which takes into account the difference between the real and ideal fixation of the flat spring [6]. 
In the case when there are used eight flat springs $\left(i^{\prime}=8\right)$, and when there is ensured a large ratio of the thickness $a$ of the spring's working part to the thickness of the spring's fixed part ( $>5$ ), we can adopt $k_{3} \rightarrow 1$, and the expression (9) can be rewritten as:

$$
a=2,86 \cdot 10^{-4} \cdot l_{2} \cdot \sqrt[3]{\frac{v_{o b}^{2} \cdot m_{B}}{b}} .
$$

In order to ensure the necessary durability of the device operation, the stresses occurring in the spring elements during their bending should be less than admissible ones. For the quality (fine) heat-treated spring steel (e.g., for $60 \mathrm{C} 2$ steel quality), the admissible stress is $\left[\sigma_{-1}\right]=3 \cdot 10^{8} \mathrm{~Pa}$. According to $[5,9]$, the bending stresses occurring in springs can be determined by the following formula:

$$
\sigma=\frac{3 \cdot E \cdot d \cdot y}{l^{2}} \leq\left[\sigma_{-1}\right]
$$

where $y$ is the deflexion the spring.

Taking into account the expression (3) and the necessary amplitudes of vibrations depending on the springs' deflexion, we obtain the formula for determining the minimal length of the circular rod-type spring:

$$
l_{1 \min }=5.58 \cdot \sqrt[5]{\frac{E^{3} \cdot v_{0 n-n}^{2} \cdot y_{n-n}^{4} \cdot m_{n-n}}{\left[\sigma_{-1}\right]^{4} \cdot i}} .
$$

For the design with $i=12$ and with steel springs, we obtain:

$$
l_{1 \min }=3.49 \cdot \sqrt[5]{v_{0 n-n}^{2} \cdot y_{n-n}^{4} \cdot m_{n-n}} .
$$

For the flat springs, the minimal length is equal to:

$$
l_{2 \min }=10.2 \cdot \sqrt[3]{\frac{E^{2} \cdot v_{0 b}^{2} \cdot y_{b}^{3} \cdot m_{b}}{\left[\sigma_{-1}\right]^{3} \cdot b \cdot i^{\prime} \cdot k_{3}}}
$$

where $y_{b}$ is the deflexion of vertical springs.

In the case when $i^{\prime}=8$, the simplified expression (14) can be rewritten as:

$$
l_{2 \min }=0.565 \cdot \sqrt[3]{\frac{v_{0 b}^{2} \cdot y_{b}^{3} \cdot m_{b}}{b}} .
$$

The natural frequency $v_{06}$ of vertical vibrations is to be chosen according to the recommendations presented in $[5,9]$ and should be $1.15 \ldots 1.3$ times larger than the forced frequency.

The deflexion of the springs of vertical vibrations: 


$$
y_{\theta}=A_{1,2 b} \cdot\left(1+\frac{m_{1}+m_{2}}{m_{3}}\right) \text {, }
$$

where $A_{1,26}$ is the amplitude of vertical vibrations of the masses $m_{1}, m_{2}$, which vibrate as one body. Taking into account the necessity to provide the intact conveying of products, the value of $A_{1,2 b}$ should be following [5]: 1) for the frequency of $v=50 \mathrm{~Hz}-A_{1,2 \beta}=0.1 \mathrm{~mm}$; for the frequency of $v=25 \mathrm{~Hz}-A_{1,2 \beta}=0.4 \mathrm{~mm}$. vibrations:

The deflexion of the rod-type springs under the conditions of longitudinal and lateral

$$
y_{n-n}=A_{1 n-n} \cdot\left(1+\frac{m_{1}}{m_{2}+m_{3}}\right) \text {, }
$$

where $A_{1 n-n}$ is the amplitude of vibrations of the mass $m_{1}$, which can be determined taking into account the necessary conveying speed:

$$
V_{m p}=2 \cdot \pi \cdot v \cdot A_{1 n-n} \cdot k_{u},
$$

where $k_{u}=0.6 \ldots 0.7$ is the coefficient of the conveying speed.

In the case of diagonal conveying, the amplitude of vibrations is equal to the vector sum of the component amplitudes of longitudinal and lateral vibrations.

Using the formulas (4) and (11), we can derive the expression for determining the diameters $d$ of circular rod-type springs ensuring their strength:

$$
d=5.8 \cdot 10^{-3} \cdot v_{0 n-n}^{0.8} \cdot m_{n-n}^{0.4} \cdot y_{n-n}^{0.6}
$$

Similarly, for the flat springs, we obtain the necessary thickness:

$$
a=1.72 \cdot 10^{-4} \cdot \frac{v_{0 b}^{4 / 3} \cdot y_{b} \cdot m_{b}^{2 / 3}}{b^{2 / 3}} .
$$

\section{Example of determining the parameters of vibratory conveying and manipulating} device. On the basis of the proposed design diagram (Fig. 2), there was developed, manufactured and investigated the experimental prototype of the conveying and manipulating machine with the following parameters: 1) the dimensions of the working plate $500 \times 500 \mathrm{~mm}$; 2) the values of the oscillating masses $m_{1}=30 \mathrm{~kg}, m_{2}=30 \mathrm{~kg}, m_{3}=15 \mathrm{~kg}$;3) the number of cylindrical rod-type springs $i=12$;4) the number of flat springs $i^{\prime}=8$.

For the given conveying speed $V_{m p}=0,2 \mathrm{~m} / \mathrm{s}$ and forced frequency $v=50 \mathrm{~Hz}$, in accordance with (18), the amplitude of the longitudinal and natural vibrations of the working plate is following:

$$
A_{1 n-n}=\frac{V_{m p}}{2 \cdot \pi \cdot v \cdot k_{u}}=\frac{0.2}{2 \cdot \pi \cdot 50 \cdot 0.6}=10^{-3} \mathrm{~m} .
$$


The reduced mass of the system under the conditions of longitudinal and lateral vibrations is equal to:

$$
m_{n-n}=\frac{m_{1} \cdot\left(m_{2}+m_{3}\right)}{m_{1}+m_{2}+m_{3}}=\frac{30 \cdot(30+15)}{30+30+15}=18 \mathrm{~kg}
$$

In accordance with (17), the springs' deflexion under the conditions of longitudinal and lateral vibrations is following:

$$
y_{n-n}=A_{1 n-n} \cdot\left(1+\frac{m_{1}}{m_{2}+m_{3}}\right)=10^{-3} \cdot\left(1+\frac{30}{30+15}\right)=1.66 \cdot 10^{-3} \mathrm{~m} .
$$

Adopting $v_{0 n-n}=53 \mathrm{~Hz}$ and using the formula (13), we can determine the working length of the rod-type springs:

$$
l_{1 \min }=3.49 \cdot \sqrt[5]{v_{0 n-n}^{2} \cdot y_{n-n}^{4} \cdot m_{n-n}}=3.49 \cdot \sqrt[5]{53^{2} \cdot\left(1.66 \cdot 10^{-3}\right)^{4} \cdot 18}=0.182 \mathrm{~m} .
$$

Adopting $l_{1}=0.185 \mathrm{~m}$, let us determine the diameters of the rods with a help of formula (4):

$$
d=2.27 \cdot 10^{-3} \cdot \sqrt[4]{v_{0 n-n}^{2} \cdot m_{n-n} \cdot l_{1}^{3}}=2.27 \cdot 10^{-3} \cdot \sqrt[4]{53^{2} \cdot 18 \cdot 0.185^{3}}=9.6 \cdot 10^{-3} \mathrm{~m} .
$$

Adopting $i^{\prime}=8, b=0.08 \mathrm{~m}, A_{1,26}=10^{-4} \mathrm{~m}, v_{06}=58 \mathrm{~Hz}, k_{3}=1$, let us determine the reduced mass $m_{b}=\frac{m_{3} \cdot\left(m_{1}+m_{2}\right)}{m_{1}+m_{2}+m_{3}}=\frac{15 \cdot(30+30)}{30+30+15}=12 \mathrm{~kg}$ and the deflexion of the flat springs $y_{B}=A_{1,2 B} \cdot\left(1+\frac{m_{1}+m_{2}}{m_{3}}\right)=10^{-4} \cdot\left(1+\frac{30+30}{15}\right)=5 \cdot 10^{-4} \mathrm{~m}$. Therefore, the minimal length of the flat springs can be determined in accordance with (15):

$$
l_{2 \min }=0.565 \cdot \sqrt[3]{\frac{v_{0 b}^{2} \cdot y_{B}^{3} \cdot m_{B}}{b}}=0.565 \cdot \sqrt[3]{\frac{58^{2} \cdot\left(5 \cdot 10^{-4}\right)^{3} \cdot 12}{0.08}}=0.0225 \mathrm{~m}
$$

Since there is a necessity the ensure the frequency reserve for vertical vibrations (e.g., when using detached vibratory conveying), taking into account the design peculiarities of the proposed device, the working length of the flat spring of vertical vibrations was adopted as:

$$
l_{2}=2 \cdot l_{2 \min }=2 \cdot 0.0225=0.045 \mathrm{~m} \text {. }
$$

Therefore, the thickness of the flat spring of vertical vibrations can be determined according to the formula (9):

$$
a=l_{2} \cdot \sqrt[3]{\frac{4 \cdot \pi^{2} \cdot v_{0 b}^{2} \cdot m_{b}}{E \cdot b \cdot i^{\prime} \cdot k_{3}}}=0.045 \cdot \sqrt[3]{\frac{4 \cdot \pi^{2} \cdot 58^{2} \cdot 12}{2.1 \cdot 10^{11} \cdot 0.08 \cdot 8 \cdot 1}}=0.001 \mathrm{~m} .
$$


Using the expression (20) for flat springs, and taking into account the strength conditions and the double increase of the vertical deflexion, we can write:

$$
a=1.72 \cdot 10^{-4} \cdot \frac{58^{4 / 3} \cdot\left(2 \cdot 5 \cdot 10^{-4}\right) \cdot 12^{2 / 3}}{0.08^{2 / 3}}=0.001 \mathrm{~m}
$$

The obtained results substantiate the adequacy of the derived formulas. Thus, they can be used by engineers and researchers while designing and investigating new vibratory equipment based on the proposed structure.

Operational peculiarities of the improved machine. The proposed conveying and manipulating device operates as follows. The power is applied to the electromagnets' coils from the three-phase network of alternating current through the voltage regulator and half-wave rectifier. If the voltage is applied to two pairs of electromagnets' coils 14, 16 and 15, 17 of longitudinal vibrations through two rectifiers (diodes) connected oppositely (Fig. 3, the power is supplied according to the push-pull (two cycle) circuit), there are implemented the longitudinal vibrations of masses in horizontal plane. If we similarly apply the voltage to two pairs of electromagnets' coils 18, 20 and 19,21, there are implemented the lateral vibrations of masses in horizontal plane. Horizontal longitudinal and horizontal lateral harmonic vibrations do not provide vibratory conveying of parts placed on the conveying plate. If the voltage if applied to the electromagnet's coil 22 of vertical vibrations through the half-wave rectifier according to the push-pull (two-cycle) circuit (Fig. 3), there are implemented vertical vibrations of masses. The amplitudes of these vibrations can be changed by means of changing the voltage value applied to the corresponding electromagnets. The working and the intermediate masses vibrate in antiphase. The coils of electromagnets of vertical and horizontal vibrations are supplied from different phases of the three-phase power network.

If the vertical acceleration of the conveying plate does not exceed the free-fall acceleration or if $W=\frac{A_{b} \cdot \omega^{2}}{g} \leq 1$ (where $A_{b}$ is the amplitude of vertical vibrations, $\omega=2 \cdot \pi \cdot v$ is forced cyclic frequency of oscillations), the parts move on the conveying plate with no rising off (detaching) it.

If the voltage is simultaneously (concurrently) applied to the electromagnets of longitudinal (lateral) and vertical electromagnets from different phases (Fig. 3), depending on the method of switching the phases and rectifiers, the conveying plate performs elliptical vibrations in longitudinal or lateral direction.

The reversal direction of conveying can be provided by means of changing the switching method of the mutually opposite diodes or the diode of the electromagnet of vertical vibrations. If the electromagnets of longitudinal and lateral vibrations are simultaneously (concurrently) connected to the same phase and the electromagnet of vertical vibrations is powered in accordance with the single-cycle circuit from the other phase, and when the independent pushpull (two-cycle) power supply circuit is used for applying different controlled voltages to the electromagnets of longitudinal and lateral vibrations, the device can convey parts in any direction of the working plate.

The direction of conveying depends on the ratio of amplitudes of longitudinal and lateral vibration and on the method of witching the coils of corresponding electromagnets. The optimal phase shift between the voltages applied to the electromagnets of horizontal and vertical vibrations is in the range of $60^{\circ} \ldots 90^{\circ}$ (in some cases it can reach $120^{\circ}$ ). Such phase shifts can be provided by the special device called phase shifter. 
Let us consider the case when the electromagnet of vertical oscillations is not powered. If we apply the same voltage to the electromagnets of longitudinal and lateral vibrations in accordance with the push-pull (two-cycle) circuit ensuring the phase shift of 90 between them, each point of the conveying plate will be circumscribing a circle. Then the pars with small contact pressure (ratio of the part's weight to the area of its contacting surface) placed on the conveying plate will rotate about their longitudinal axes regardless of where they are located due to the different friction forces in different contact points. The sense (direction) of the parts' rotation depends on the phase shift between the longitudinal and lateral vibrations $\left(90^{\circ}\right.$ or $\left.270^{\circ}\right)$.

If the in-phase voltage is applied to the electromagnets $15,16,18,21$ and the other four electromagnets 14, 17, 19, 20 operate at the opposite phase (Fig. 4), there occurs the angular moment trying to transport the parts along the circular paths (trajectories). If the electromagnet of vertical vibrations is powered, then the parts are conveyed along the circular paths about the vertical axis of the structure symmetry. The direction of the parts motion (clockwise or anticlockwise) depends on the the phase shift between the voltages applied to electromagnets $15,16,18,21$ and 14, 17, 19, 20. The radius of the path of parts conveying depends on the initial position of the parts at the beginning of conveying process.

We can use the mentioned above operation mode if we need to build up (gather) the parts on the plate in helical grooves (Fig. 5, b). In addition, we can discharge the conveyer switching the reversal motion of parts.

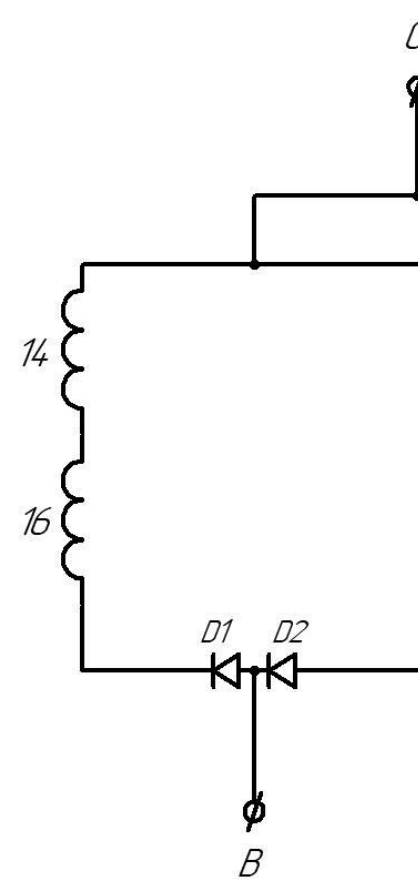

Figure 3. Power supply circuit of the electromagnets of horizontal longitudinal and vertical vibrations for implementing the longitudinal vibratory conveying

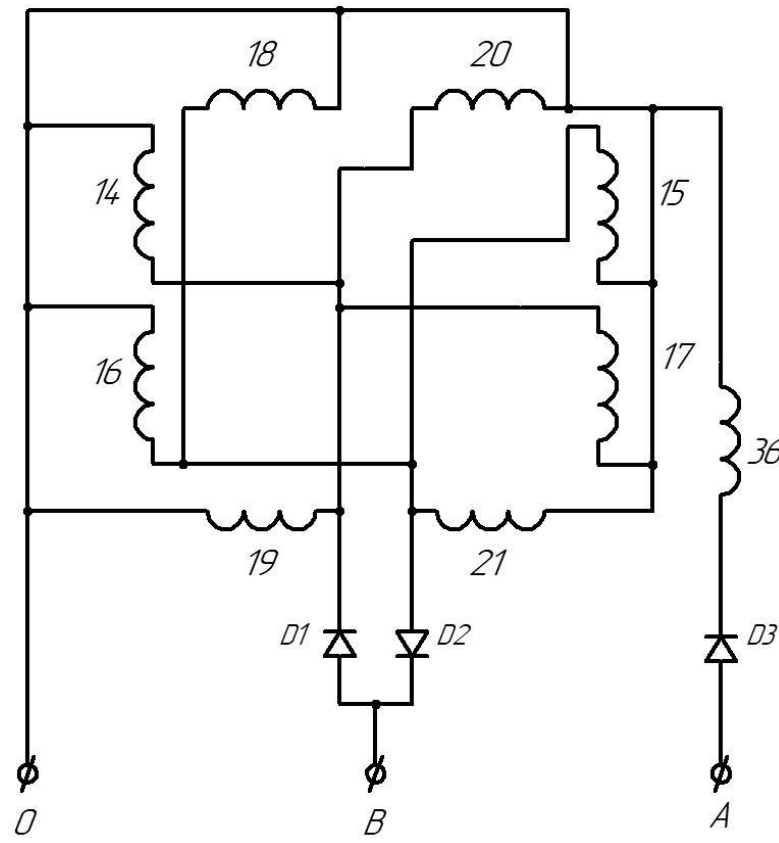

Figure 4. Power supply circuit of the electromagnets of longitudinal, lateral and vertical vibrations for implementing the vibratory conveying along the circular paths

The improved conveyer (Fig. 2) allows moving the piece products in any direction of the working plate with their simultaneous rotating about their longitudinal axes (Fig. 5, a), as well as moving the parts along the circular paths (Fig. 5, b). 


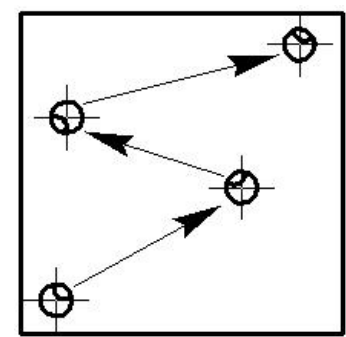

a)

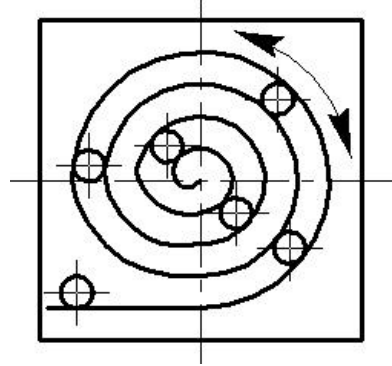

b)

Figure 5. The methods of conveying piece products with a help of the improved device: a - in any direction of the working plate with simultaneous rotation; $b$ - along the circular paths

The principal schemes of vibratory conveying and technological systems developed on the basis of the proposed machine are presented in Fig. 6.

According to the scheme in Fig. 6, a, the parts fed by the belt conveyer to the vibratory device are distributed in three directions and charge other belt conveyers. The scheme in Fig. 6, c, presents the process of dense (compact) building up (gathering) the parts on the plate. According to the scheme in Fig. 6, b, the parts are built up (gathered) in the spiral hopper (magazine) and then are fed to another conveyer. The scheme in Fig. 6, d, provides the placement of products on the moving belt of the conveyer [8]. The density (compactness) of the parts placement depends on the feeding speed and belt speed.



a)

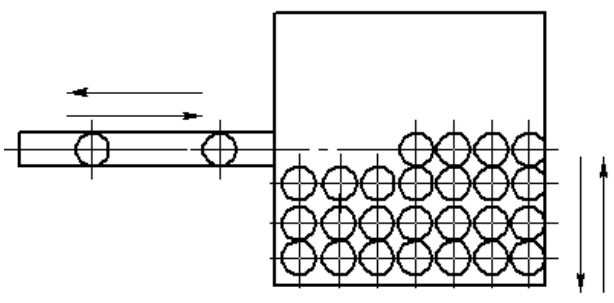

c)

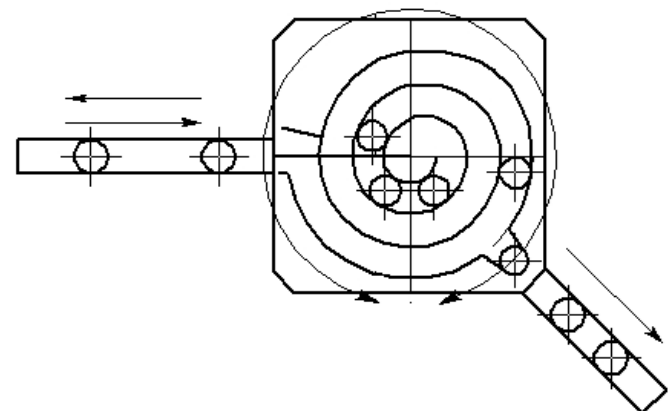

b)

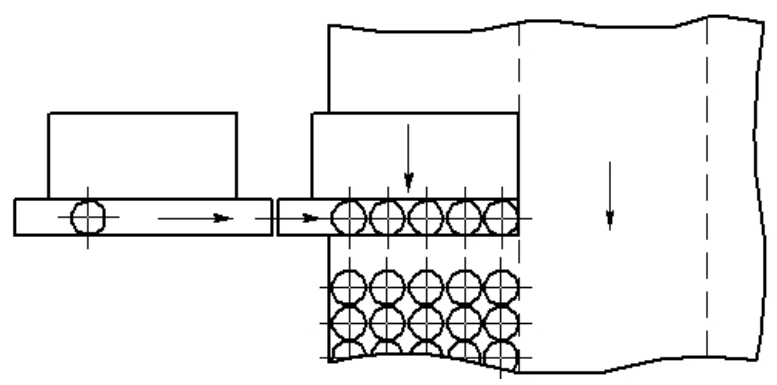

d)

Figure 6. Principal schemes of vibratory conveying and manipulating systems: a - feeding the parts to the vibratory device and their distributing in three directions; $b$ - gathering the parts in the spiral hopper (magazine); $\mathrm{c}$-dense (compact) building up (gathering) the parts on the plate; $\mathrm{d}$ - placing the products on the moving belt of the conveyer 


\section{Conclusions.}

1. The improved design of the vibratory conveying and manipulating device was developed. Its structural and operational peculiarities, as well as major advantages, were considered. The possibilities of conveying piece products with a help of the improved device were analysed.

2. The methodology of designing and determining inertial, stiffness and excitation parameters of the improved vibratory machine was developed. The example of calculating the parameters of its mechanical vibratory system was presented.

3. The power supply circuits of the electromagnetic drive of the improved device were developed. One of the circuits was used for providing longitudinal vibratory conveying, and the second one - for implementing the vibratory conveying along the circular paths.

4. The principal schemes of vibratory conveying and technological systems developed on the basis of the proposed machine were considered. In particular, the processes of distributing the parts in three directions, gathering the parts in the spiral hopper, dense (compact) building up (gathering) the parts on the plate, and placing the products on the moving belt of the conveyer were analysed.

\section{References}

1. Povidajlo V.A. Vibracionnyj konvejer. Copyright certificate SU 1033393 A, B 65 G 27/08, 1983. [In Russian].

2. Povidajlo V.A. Vibracionnoe ustrojstvo avtomaticheskogo gruppovogo orientirovaniya izdelij. Copyright certificate SU 1033395, B 65 G 27/32, 1983. [In Russian].

3. Lavendel E.E., et al. Vibratcionnye protcessy i mashiny. Moscow: Mashinostroenie, 1981, 509 p. [In Russian].

4. Blyaxerov I.S., et at. Avtomaticheskaya zagruzka texnologicheskix mashin. Moskva, Mashinostroenie Publ., 1990, 400 p. [In Russian].

5. Povidailo V.O. Vibratsiini protsesy ta obladnannia. Lviv, Vydavnytstvo Natsionalnoho universytetu «Lvivska politekhnika», 2004, 248 p. [In Ukrainian].

6. Shenbor V., Koruniak P., Korendiy V., Brusentsov V., Brusentsova M. Analysis and Improvement of TwoMass Vibrating Tubular Conveyers with Two-Cycle Electromagnetic Drive. Ukrainian Journal of Mechanical Engineering and Materials Science, 2016, vol. 2, no. 1, pp. 55 - 64.

7. Koruniak P., Shenbor V., Korendiy V., Bezpalov A., Brusentsov V. Ways of Improvement of Operational Efficiency of Hopper Devices. Ukrainian Journal of Mechanical Engineering and Materials Science, 2016, vol. 2 , no. 2 , pp. $79-87$.

8. Korendii V.M., Havrylchenko O.V., Shenbor V.S. Vibratsiini transportno-manipuliuiuchi konveiery dlia pakuvalnoho obladnannia. Visnyk Natsionalnoho universytetu «Lvivska politekhnika». Seriia: Optymizatsiia vyrobnychykh protsesiv i tekhnichnyi kontrol u mashynobuduvanni ta pryladobuduvanni Bulletin of Lviv Polytechnic National University. Series: Optimization of Production Processes and Technical Control in Mechanical Engineering and Instrument Making, 2018, no. 891, pp. 35 - 41. [In Ukrainian].

9. Ivanov A.A. Proektirovanie sistem avtomaticheskogo manipulirovaniya miniatyurnymi izdeliyami. Moskva, Mashinostroenie Publ., 1981, 271 p. [In Russian].

10. Povidajlo V.A., Stocko Z.A. Proizvoditel'nost' processa gruppovoj zagruzki kasset sposobom vibrotransportirovaniya detalej po poverxnosti kassety. Avtomatizaciya proizvodstvennyx processov v mashinostroenii i priborostroenii - Automation of Production Processes in Mechanical Engineering and Instrument Making, 1973, vol. 13, pp. 123 - 127. [In Russian].

11. Shhigel' V.A., Stocko Z.A. Raschyot partii izdelij dlya vibracionnogo zapolneniya kasset-magazinov. Avtomatizaciya proizvodstvennyx processov $\mathrm{v}$ mashinostroenii i priborostroenii - Automation of Production Processes in Mechanical Engineering and Instrument Making, 1978, vol. 17, pp. 92 - 96. [In Russian]. 
Список використаної літератури

1. А.c. 1033393 СССР, В 65 G 27/08. Вибрационный конвейер [Текст] / В.А. Повидайло (СССР). № 3421660/27-03; заявл. 12.04.82; опубл. 07.08.83; Бюл. № 29.

2. А.c. 1033395 СССР, В 65 G 27/32. Вибрационное устройство автоматического группового ориентирования изделий [Текст] / В.А. Повидайло (СССР). - № 3423877/27-03; заявл. 12.04.82; опубл. 07.08.83; Бюл. № 29.

3. Вибрации в технике: Справочник. В 6-ти т. / Ред. совет: В.Н. Челомей (пред.). - Т. 4. Вибрационные процессы и машины: под ред. Э.Э. Лавендела. - М.: Машиностроение, 1981. - 509 с.

4. Автоматическая загрузка технологических машин [Текст] / И.С. Бляхеров и др. - М.: Машиностроение, 1990. - 400 с.

5. Повідайло, В.О. Вібраційні процеси та обладнання [Текст] / В.О. Повідайло. - Львів: Видавництво Національного університету «Львівська політехніка», 2004. - 248 с.

6. Shenbor, V. Analysis and Improvement of Two-Mass Vibrating Tubular Conveyers with Two-Cycle Electromagnetic Drive [Текст] / V. Shenbor, P. Koruniak, V. Korendiy, V. Brusentsov, M. Brusentsova // Ukrainian Journal of Mechanical Engineering and Materials Science. - 2016. - vol. 2, no. 1. - pp. 55 - 64.

7. Koruniak, P. Ways of Improvement of Operational Efficiency of Hopper Devices [Text] / P. Koruniak, V. Shenbor, V. Korendiy, A. Bezpalov, V. Brusentsov // Ukrainian Journal of Mechanical Engineering and Materials Science. - 2016. - Vol. 2, no. 2, - pp. $79-87$.

8. Корендій, В.М. Вібраційні транспортно-маніпулюючі конвеєри для пакувального обладнання [Текст] / В.М. Корендій, О.В. Гаврильченко, В.С. Шенбор // Вісник Національного університету «Львівська політехніка». Серія: Оптимізація виробничих процесів і технічний контроль у машинобудуванні та приладобудуванні. - 2018. - № 891. - С. 35 - 41.

9. Иванов, А.А. Проектирование систем автоматического манипулирования миниатюрными изделиями [Текст] / А.А. Иванов. - М.: Машиностроение, 1981. - 271 с.

10. Повидайло, В.А. Производительность процесса групповой загрузки кассет способом вибротранспортирования деталей по поверхности кассеты [Текст] / В.А. Повидайло, 3.А. Стоцко // Автоматизация производственных процессов. - 1973. - Вып. 13. - С. 123 - 127.

11. Щигель, В.А. Расчёт партии изделий для вибрационного заполнения кассет-магазинов [Текст] / В.А. Щигель, 3.А. Стоцко // Автоматизация производственных процессов в машиностроении и приборостроении. - 1978. - Вып. 17. - С. 92 - 96.

\title{
УДК 621.867
}

\section{УДОСКОНАЛЕННЯ ВІБРАЦІЙНИХ ТРАНСПОРТНО- МАНІПУЛЮЮЧИХ МАШИН}

\author{
Віталій Корендій; Владислав Шенбор; Олександр Гаврильченко; \\ Володимир Брусенцов
}

\author{
Начіональний університет «Львівська політехніка», Львів, Украйна
}

Резюме. Вібраиійні транспортуючі машини з електромагнітним приводом коливань упродовж кількох останніх десятиліть з успіхом застосовуються для механізації та автоматизації різних виробництв. Одним із найпоширеніших типів такого обладнання є машини з еліптичними режимами коливань транспортуючих елементів. Застосування багатокомпонентного електромагнітного привода коливань і металевих пружних елементів у вигляді плоских, траткових і стержневих пружин дозволило створити нові моделі транспортуючих $і$ транспортно-маніпулюючих машин. Їх особливостями $\epsilon$ незалежне надання транспортуючій площині коливань за трьома координатами з керованим зсувом фаз між компонентами коливань. Нескінченна множина комбінацій таких коливань дозволяє транспортувати вироби, щзо знаходяться на транспортуючій площчин, за будь-яким напрямком та обертати деталі в будь-якій точцฺі площчини за чи проти годинникової стрілки. Технічні можливості 
таких машин дозволяють групувати і розподіляти вироби, подавати вироби на інше обладнання, касетувати вироби та здійснювати низку інших транспортних і транспортно-технологічних операчій. $B$ даній публікації запропоновану удосконалену модель транспортно-маніпулюючої машини. Вона має три коливальні маси, вісім електромагнітних віброзбудників горизонтальних та один електромагнітний віброзбудник вертикальних коливань. Пружна система складається зі стержневих пружин, встановлених у вертикальних площинах, що з'єднують робочу і проміжну маси. Для вертикальних коливань застосовано плоскі пружини, встановлені в горизонтальній площчині, які з'єднують проміжну $і$ реактивну маси. Коливальні системи горизонтальних і вертикальних коливань налаштовуються на білярезонансний режим роботи, забезпечуючи малу споживану потужність $і$ достатню стабільність роботи 3 можслиістю транспортування виробів у широкому діапазоні мас завантаження. Удосконалена конструкиія додатково дозволяє транспортувати деталі по колах різного радіуса відносно ичентральної вертикальної осі симетрії пристрою. В публікаиії розроблено методику розрахунку пружної системи пристрою на жорсткість та мічність. Отримані залежності дають можливість застосовувати їх на етапах проектування таких машин, або робити перевіркові розрахунки за наявності ескізного проекту пристрою. Розроблено методику розрахунку пружної системи кутових коливань. Для розробленої моделі пристрою розмірами транспортуючої площини 500×500 мм проведено розрахунки пружної системи на жорсткість і міцуність. Розглянувщи можливості кількох систем живлення електромагнітного привода удосконаленої машини, розроблені принцииові схеми різних транспортно-технологічних систем із ї̈ використанням.

Ключові слова: вібрачійний конвеєр, транспортно-маніпулюючий пристрій, пружна система, вібрація, конструктивна схема, принц̧ипова електрична схема, автоматизація виробництва.

https://doi.org/10.33108/visnyk_tntu2018.04.068

Отримано 25.12.2018 